\title{
Balla ewako : community response to the COVID-19 pandemic based on local wisdom
}

\author{
Ahmad Fatkul Fikri ${ }^{*}$, Syamsul Maarif ${ }^{1}$, Dody Ruswandi ${ }^{1}$, Titisari Haruming Tyas ${ }^{1}$, and Islamia Kharimah $^{1}$ \\ ${ }^{1}$ Disaster Management Study Program, National Security Faculty, Republic of Indonesia Defense University. IPSC Sentul Area, \\ Bogor, West Java, Indonesia
}

\begin{abstract}
The COVID-19 pandemic has entered a new phase with the discovery of new variants from several countries entering Indonesia. This epidemic is capable of destroying the joints of people's lives, such as health, education, politics, economics, social, culture, politics to the point of disrupting regional resilience. Various efforts have been made by the government in the context of dealing with COVID-19 which cannot be ascertained to end. This research has the aim of analyzing the other side of the COVID-19 pandemic in the form of local wisdom. This study uses descriptive qualitative data obtained through interviews, observation, and documentation. The analytical technique used is the Miles, Huberman, and Saldana model. The results of this study indicate that the local wisdom of Balla Ewako has the meaning of a tough house in the face of the COVID-19 pandemic. Balla Ewako is a tough village program by the South Sulawesi Regional Police which later became a movement for the community in dealing with the COVID-19 pandemic based on local wisdom. The Balla Ewako program has the goal of a strong village for health, food resilience. and security with direct community involvement. Balla Ewako has proven to be effective in tackling the COVID-19 pandemic by mobilizing all elements of the grassroots community.
\end{abstract}

\section{Introduction}

In the current era of technological progress, countries in the world are focused on fighting for the safety of mankind, including Indonesia. As a country, Indonesia is required to protect the entire nation and the entire homeland of Indonesia. This mandate has been stated in the Preamble to the 1945 Constitution of the Republic of Indonesia. The statement is the state's promise to its people to be able to live in prosperity and safety from various kinds of threats. The real threat facing the Indonesian nation today is a disaster.

Disasters come in various forms, ranging from natural disasters to man-made disasters that affect people's lives. One of the factors that cause disasters is a pandemic. World history records epidemics that have been experienced by health, for example, the Peloponnesian Pandemic (430 BC), the Justinian Plague (527-565 AD), the Black Death pandemic (1347-1351 AD), smallpox which occurred in 1492, cholera around 1961, the Spanish Flu in 1918-1919, the 2003 SARS outbreak, the 2009 Swine Flu, the 2014 Ebola pandemic and most recently the COVID-19 pandemic $[1,2,3]$. While the pandemic in Indonesia was recorded during the reign of King Airlangga in 1006-1042 AD, and what is currently happening is the COVID-19 pandemic [4].

To date, the struggle of countries in the world to face the COVID-19 pandemic has not ended, including in Indonesia. Corona Virus Disease 2019 (COVID-19) is a disease caused by a virus called Severe Acute Respiratory Syndrome CoronaVirus-2 (SARS-CoV-2) [5]. COVID19 is called a zoonotic virus, which is a disease that is transmitted from animals to humans, with the first case in a wet market selling wild animals in Wuhan City, China [6]. COVID-19 spreads faster and more massively than the SARS and MERS outbreaks [7]. Based on this, on March 11, 2020, the World Health Organization (WHO) declared COVID-19 a global pandemic. Countries in the world, whether they are developed or underdeveloped, rich or poor, have all been affected by COVID-19.

Based on data from the World Health Organization (WHO) until June 24, 2021, there were more than 179 million confirmed cases of COVID-19, 3.8 million more of whom died spread over 223 countries in the world. While in Indonesia, on June 24, 2021, there were 2.053.995 confirmed cases of COVID-19, 55.949 people died from the virus. Not only taking lives, but the effects of the COVID-19 pandemic have also extended to aspects of social, political, economic, cultural, tourism, education to defense and security and the worst thing is the household $[8,9,10,11]$. This condition has prompted the central and regional governments to work hard in dealing with the COVID-19 emergency. The COVID-19 emergency period in Indonesia was established through Presidential Decree No. 12 of 2020 concerning the Status of COVID-19 Non-Natural Disasters as National Disasters. A disaster emergency has the meaning of a condition that threatens and disrupts the order of people's

\footnotetext{
*Corresponding Author: ahmadfatkulfikri02@gmail.com
} 
lives due to natural, non-natural causes that result in casualties, damage, and psychological disorders.

To achieve success in dealing with the COVID-19 pandemic, good policies from the government and public awareness are needed. Various efforts have been made by the government to suppress the spread of COVID-19 by involving health workers to volunteers. However, all the government's efforts and strategies have encountered obstacles when people don't care about this virus. Low literacy skills encourage people to be indifferent to the handling of COVID-19 so that public understanding of the dangers of COVID-19 is very low $[12,13]$. The existence of a vaccine does not guarantee that this pandemic will end soon. The active participation of the community in building awareness and responsibility is the key to success in ending this pandemic. However, the diverse and particularistic conditions of Indonesian society are not easy for the government to do. A cultural approach is needed as an alternative route with the complex social conditions of the Indonesian nation.

Culture is an important foundation for present and future people's lives [14]. Local wisdom is in the form of knowledge, myths, and ancestral messages containing prohibitions, invitations, and sanctions in environmental management. Local wisdom includes life values that apply to the community in being wise, full of wisdom, and local ideas that are embedded and followed by residents to protect a sustainable environment [15]. Local wisdom also consists of a view of life and knowledge, consisting of various livelihood strategies to solve life's problems [16]. Local wisdom is important to be preserved to maintain the balance and sustainability of the environment. Having local knowledge of adapting and interacting with the environment to find adaptation strategies to the environment at the local level [17]. Positive things in culture This is called local wisdom. Koentjaraningrat, Spradley, Taylor, and Suparlan, have categorized the human culture which is the container of local wisdom to ideas, social activities, artifacts [18].

As a country that has a variety of cultures, there are various kinds of unique ethnic customs that are different for each tribe. Most of the tribes in Indonesia have local wisdom that can be used to fight the COVID-19 pandemic as it is today. One solution to overcome the problems that occur in the community to overcome COVID-19 is cultural power [14]. One of the local wisdom to fight the COVID-19 pandemic is Balla Ewako who is in the community of South Sulawesi. Balla Ewako is an activity to help each other between communities in terms of health, economy, and security during the COVID-19 pandemic.

As an area with a strong culture, Palopo City has an alternative in dealing with the COVID-19 pandemic. Based on this background, it is deemed necessary to research to determine the application of local wisdom in the form of Balla Ewako to the people of Palopo City as a risk reduction for the COVID-19 pandemic based on local wisdom. Broadly speaking, this research will discuss the other side of dealing with the COVID-19 pandemic, namely the local wisdom approach.

\section{Method}

This study uses a qualitative method with a descriptive approach. Researchers describe the situation under study by enriching the information and looking for relationships to answer why and how the phenomenon occurs. It is similar to the view of Nazir that descriptive methods are used to examine the status of a group of people, an object, a set of conditions, a system of thought, or a class of events in the present [19]. The subjects of this research are parties who are directly involved as resource persons and understand the research topic. The research subjects were selected by purposive sampling, meaning that the specified resource persons had met the specified criteria. The resource persons in question are the Lurah, Babhinkamtibmas, and Babinsa in Palopo City.

In this study, the data needed are primary and secondary. Techniques for providing data using interviews, observation, and documentation. The data analysis technique used is an interactive model as proposed by Miles, Hubberman, and Saldana (2014) which is an analytical technique that is carried out continuously during data collection in the field until data collection is completed so that the data obtained is saturated. The interactive model data analysis technique as proposed by Miles, Hubberman, and Saldana (2014) consists of data collection, data condensation, data presentation [20], and conclusion. While the location in this study is in Palopo City as shown in Fig. 1.

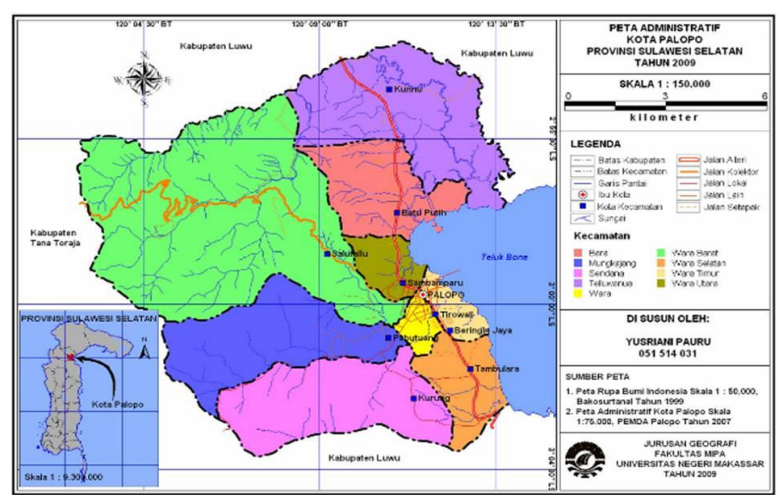

Fig. 1. Location of Area Study

\section{Result and Discussion}

\subsection{Spread of COVID-19 in Palopo City}

Coronavirus or better known as Corona Virus Disease 2019 (COVID-19) is a new virus that infects the respiratory tract [21]. This virus was first discovered in December 2019 in Wuhan City, Hubei Province, China [22]. China reported 44 patients with severe pneumonia whose cause was unknown [23]. The initial suspicion of this virus originating from bats sold in the Wuhan wet market, although animal-to-human transmission has not been confirmed, the process of human-to-human transmission has been extensively proven [24, 25]. This virus spread to almost all corners of the world until the World Health Organization (WHO) declared it a global 
pandemic on March 11, 2020, including Indonesia [26, 27].

The Indonesian government officially announced two cases of COVID-19 infection on March 2, 2020 [28]. The spread of COVID-19 occurred massively throughout Indonesia, including Palopo City, South Sulawesi. COVID-19 first entered Palopo City on April 29, 2020. The first patient was confirmed after traveling from Makassar, which is the epicenter of the COVID-19 pandemic in the South Sulawesi region. The rate of spread of COVID-19 in Palopo City continues to occur and is experiencing an increasing trend. The rate of development of positive confirmed cases can be seen in Fig. 2 .

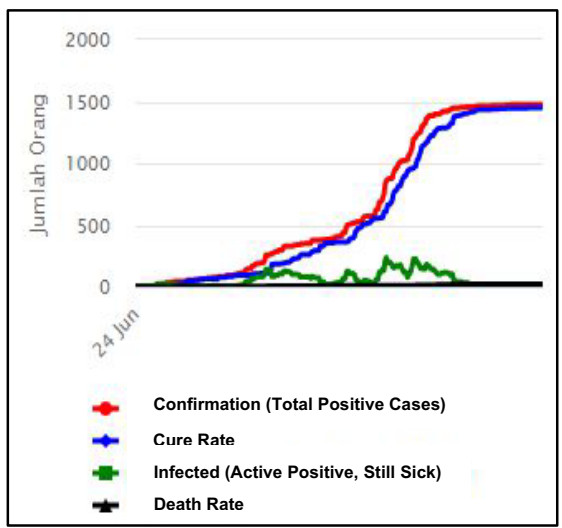

Fig. 2. The Development of Cumulative Cases of COVID-19 in Palopo City

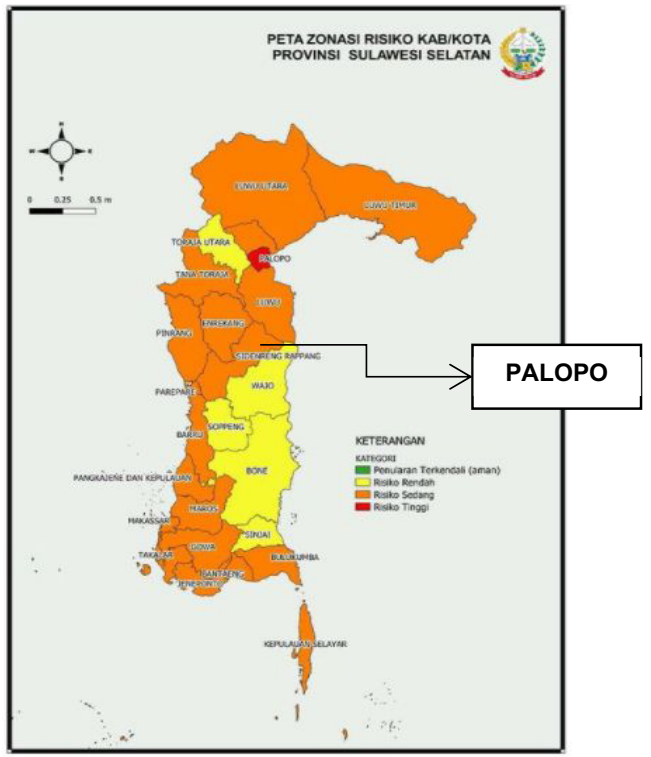

Fig. 3. Map of District/City Risk Zoning of South Sulawesi Province

Based on Fig. 2. shows that the total number of confirmed cases of COVID-19 experienced an upward trend in February 2021 and experienced a decrease in the number of confirmed cases until June 3, 2021. The decrease in the number of confirmed cases of COVID-19 was due to massive vaccination and the implementation of health protocols. While patients who died due to COVID-19 reached 54 people or $3.92 \%$. This figure is higher than the death rate in South Sulawesi Province of $1.5 \%$. The high mortality rate and low recovery rate of COVID-19 patients have pushed Palopo City as the area with the most vulnerable spread rate on October 30, 2020, as shown in Fig. 3.

On October 30, 2020, apart from the relatively low recovery rate in Palopo City, another thing that makes Palopo City still in the red zone is the high-density level. A high level of population density will have an impact on high interactions between individuals or groups in the region [29]. An area with a high population density, the higher the COVID-19 cases especially in urban areas [30]. Cities that are urban areas become catalysts in the context of the spread of infectious diseases [31]. History records that the Spanish Flu pandemic that occurred in 1918, positive confirmed cases and high deaths occurred in countries with high-density levels [32].

\subsection{Concept and Implementation of Balla Ewako}

The Balla Ewako concept is a program launched by the South Sulawesi Regional Police in the form of a tough village to accelerate the handling of the COVID-19 pandemic. Balla Ewako comes from the Bugis-Makassar language which consists of two syllables, namely Balla and Ewako. Balla means house and Ewako or Rewako means brave. In addition, the word Ewako is also used to provide encouragement or support and intimidate opponents. This program is based on the consideration that COVID-19 is contagious, namely through the breathing of people who have been infected $[33,34]$ thus placing the community at the forefront of handling the COVID-19 pandemic with the government as a supporter. As a conception, local wisdom is more easily understood by traditional communities because this community has a strong link between experience and the ability to read real phenomena [35]. This is evidenced by Prasetyo that local wisdom in traditional communities in Indonesia is an alternative in preventing disasters or in post-disaster management so that local wisdom has an important role in mitigating disasters that occur in Indonesia [36]. So that the Government can take advantage of the values of local wisdom as a step in disaster mitigation in the country.

The Balla Ewako concept is implemented in collaboration with the Lurah, Babinsa, Bhabinkabtimas, and the family community. The Balla Ewako concept is implemented by the Neighborhood Association (NA) and the Residents Association (RA) by involving the community directly overseeing the families and neighbors affected by COVID-19. This program was implemented before the implementation of the Micro-Community Activity Restriction policy in South Sulawesi. A community-based approach from the grassroots is a rational choice in dealing with the COVID-19 pandemic. Movements originating from the community in dealing with the COVID-19 pandemic, especially in their respective environments, are the main focus of the government.

The government implemented Balla Ewako as a response to the COVID-19 pandemic so that families obey the government's appeal. Balla Ewako has proven to be 
effective in the government's efforts to respond to the COVID-19 pandemic by collaborating with the community. Although not all sub-districts are aware of and understand the Balla Ewako concept, this program has proven to be able to reduce the positive number of confirmed COVID-19 in Palopo City. Since this program was issued, the community has responded well to the Balla Ewako program to respond to the COVID-19 pandemic. However, the public's adherence to the health protocols set by the government can fade, for example, the pressure to meet basic needs. This happens especially in people with middle to lower economic conditions [37]. Through the Balla Ewako movement, the government wants to achieve a resilient village in terms of health, food, and security.

First, after the Balla Ewako movement was implemented, data were found regarding the emergence of community movements to work together independently to maintain health. These activities include distributing masks for free, awareness of washing hands, awareness of using masks, checking body temperature, reporting by neighbors when there are residents who travel, and so on. The movement emerged from the community to maintain the health of every family member. Each resident takes care of the vulnerable groups in their respective homes. Vulnerable groups include those who have chronic health problems, such as heart disease, asthma, diabetes, and the elderly [38]. Older people have a higher susceptibility to coronavirus infection compared to younger people [39]. This shows that to achieve health resilience, community involvement is needed.

One of the main priorities in health empowerment is initiating the concept of work by the government that follows the current national development [40] to control the COVID-19 pandemic. The way to empower the community is to strengthen the community as a subject, not an object. The formulation and the National Health Promotion Policy states that the global health promotion strategy consists of three things, namely advocacy, atmosphere building, and community empowerment. This strategy can generally be used to address health problems and prevent health problems. Community empowerment is one of the strategies in health promotion that involves directly the participation of the community to maintain and improve their health [41].

Second, COVID-19 has had an impact on food insecurity where people experience food shortages and have to work harder to get food because some kiosks and markets have to be closed from operation [42]. The United Nations Food and Agriculture Organization (FAO) estimates that the number of people who are malnourished will increase to 132 million this year. One effort to be able to maintain the family's economic situation is to optimize food security by empowering the potential of each region [43].

During the COVID-19 pandemic, people's lives experienced difficulties, but life had to go on, therefore the government through the Balla Ewako program made donations to the community to meet the needs of daily life. To obtain food resilience, the Balla Ewako program requires the community through the kelurahan to cultivate crops on vacant land around their homes. Based on the results of interviews, the program was able to reduce public panic over the scarcity of food sources.

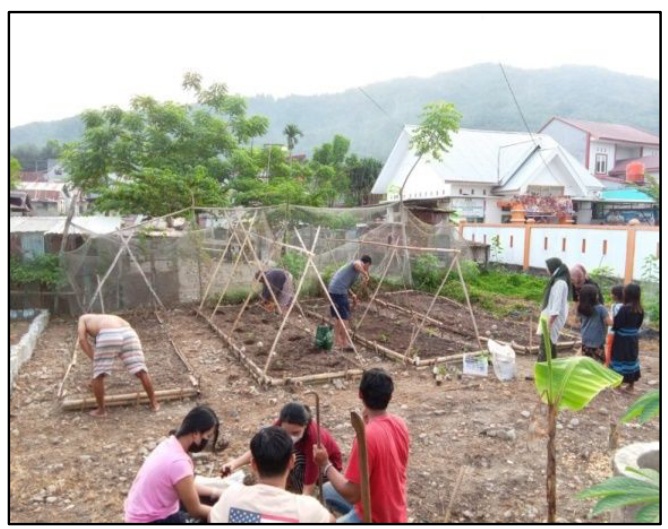

Fig. 4. Planting Process for Food Security

Food security during the COVID-19 pandemic also comes from donations from neighbors. When people are self-isolating, neighbors donate food to the neighbors. This shows that Balla Ewako brings back social capital that has been formed for a very long time. Balla Ewako generates existing social capital to survive, maintain survival and meet common needs. Social capital that has existed so far is mobilized for togetherness, establishing mutual trust and benefit, and to maintain life together.

In addition, social capital is built on mutual trust, interaction and relations between citizens, social solidarity, and norms between communities. This instrument provides community strength in dealing with the COVID-19 pandemic. Through this social capital, government programs, steps, strategies, and policies can be implemented synergistically. Social capital facilitates mutually beneficial cooperation in society because it contains networks, norms, and social beliefs that exist and is very strong in society $[44,45,46]$. Social capital can be utilized by the people of South Celebes, especially Palopo City when facing the crisis caused by the COVID-19 pandemic. Social capital is believed to be one of the main components in moving togetherness, mobility of ideas, mutual trust, and mutual benefit to achieve common goals [47].

Third, the sluggish economy due to the COVID-19 pandemic has triggered problems in public security and order. On the other hand, the government with the reason of reducing the risk of the spread of COVID-19 in detention homes freed prisoners. During the COVID-19 pandemic that has occurred in Palopo City since the beginning of 2020, the environmental security system must be strengthened. Every member of the community must carry out personal security, then maintain security in the surrounding environment. The Balla Ewako movement raises public awareness to maintain security and order in the surrounding environment. Awareness to protect the environment is done by taking care of the neighbor's house when the occupants of the house are doing maintenance in the hospital. In addition, the community independently began to limit territorial areas by using entrance portals to the area, collecting data on 
incoming guests, imposing curfews, and so on to be reported to the tough Balla Ewako village post.

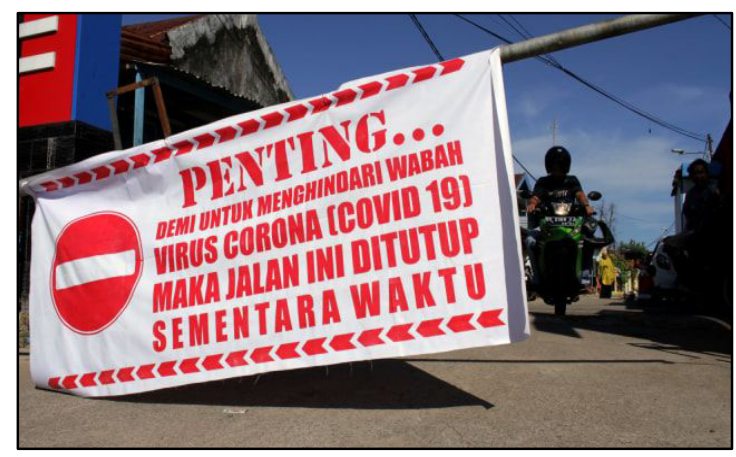

Fig. 5. quarantine portal

The environmental security system has been regulated through the Regulation of the Chief of the Police of the Republic of Indonesia Number 23 of 2007 . The regulation explains that a mobile security system is a unit that includes components that are interdependent and interconnected and influence each other which results in the ability to be used as an effort to meet the demands for security and order conditions in the environment. The environmental safety system during the COVID-19 pandemic is directed to manage so that the community obeys the health protocols set by WHO and the government. The system that needs to be built is a system that is fast and precise in preventing, socializing, and reporting mechanisms when there are symptoms that are similar to the symptoms of people infected with COVID19 [48].

\section{Conclusion and Suggestion}

Balla Ewako is a tough village program by the South Sulawesi Regional Police which later became a community movement in dealing with the COVID-19 pandemic based on local wisdom. This program uses Bugis-Makassarese phrases to provide understanding to the community. The Balla Ewako program has the goal of a strong village for health, food resilience, and security with direct community involvement. Balla Ewako has proven to be effective in tackling the COVID-19 pandemic by mobilizing all elements of the grassroots community. So far, Balla Ewako has proven to be capable of tackling the COVID-19 pandemic, because its implementation is driven by social capital that already exists and is strong in society.

\section{References}

1. Dowling, S. How global outbreaks are contained. Retrieved From https://www.bbc.com/future/article/20200422-howdisease-outbreaks-are-contained. 2020. accessed 23 Mei 2021.

2. Putri, R. H. Mass Killing Disease Outbreaks. Retrieved from https:/historia.id/sains/articles/wabah-wabah-
disease-killer-massal-P7eL5. 2020. accessed 23 May 2021.

3. Rusdi. Diachronics, 20(1), (2020).

4. Harriyadi. Disease Outbreaks in Historical Records in Indonesia. National Archaeological Center. Retrieved from http://arkenas.kemdikbud.go.id/contents/read/article/ 67ihzv_1586426994/wabah Disease-dalam-NoteSejarah-di-Indonesia\#gsc.tab=0. (2020). accessed 23 May 2021.

5. World Health Organization. Critical preparedness, readiness, and response actions for COVID-19. (World Health Organization, Geneva 2020).

6. T. Liu, J. Hu, M. Kang, L. Lin, H. Zhong, J. Xiao, G. He, T. Song, Q. Huang, Z. Rong, A. Deng, W. Zeng, X. Tan, S. Zeng, Z. Zhu, L. Li, D. Wan, J. Lu, H. Deng, J. He, and M. Ma, bioRxiv preprint. (2020).

7. M. N. K. Boulos, and E. M. Geraghty, Int'l J of Health Geo, 19(8). (2020)

8. Y. Estriyanto, DEDIKASI: Commun Service Reports, 2(2), (2020)

9. E. G. Samudro, and M. A. Madjid, J National Resilience, 26 (2), (2020)

10. Y. Sariwaty, and D. Rahmawati, J Syntax Transformation, 1(291-296), (2020)

11. S. Susilawati, R. Falefi, and A. Purwoko, Budapest International Research and Critics Institute (BIRCIJournal): Humanities and Social Sciences, 3(2), (2020)

12. D. R. Buana, GREETINGS: J Sos and Syar-i Culture, 7(3), (2020).

13. B. Yanti, H. Priyanto, and T. Zulfikar, Martabe: J Community Service, 3(1), (2020)

14. M. F. Shodiq, SALAM: J Sos dan Budaya Syar-i, 8(2), (2021)

15. Takiddin, Sos Didaktika: Social Science Education J 1(2), (2014)

16. S. Mawaddahni, Local Wisdom, 9(1), (2017)

17. D. R. Manrique, T. Völker, J. Zoghbi, and A. G. Pereira, Arctic: Traditional Knowledge, Livelihoods and Community Engagement. (Publications Office of the European Union, Luxembourg, 2018)

18. Fajarini, U, Sos Didaktika: Social Science Education J, 1(2), (2014).

19. M. Nazir, Metode Penelitian, (Ghalia Indonesia, Bogor, 2014)

20. M. B. Miles, A. M. Huberman, and J. Saldana, Qualitative Data Analysis, A Methods Sourcebook, Edition 3, (Sage Publications, USA, 2014)

21. C. C. Lai, T. P. Shih, W. C. Ko, H. J. Tang, and P. R. Hsueh, Int'1 J Of Antimicrobial Agents, 55(3), (2020)

22. H. Lu, C. W. Stratton, Y. W. Tang, J of Medical Virology, 92(4), (2020)

23. D. Handayani, D. R. Hadi, F. Isbaniyah, E. Burhan, and H. Agustin, J Respirologi Indonesia, 40 (2), (2020) 
24. F. K. Ayittey, C. Dzuvor, M. K. Ayittey, N. B. Chiwero, and A. Habib, J of Medical Virology, 92 (4), (2020)

25. M. A. Shereen, S. Khan, A. Kazmi, N. Bashir, and R. Siddique, J of Advanced Research, 24, (2020)

26. I. Wahidah, N. F. S. Hartono, M. A. Septiadi, R. Athallah, and M. C. A. Rafqie, J Manajemen dan Organisasi, 11(3), (2020)

27. Karyono, Rohadin, and D. Indriyani, J Kolaborasi Resolusi Konflik, 2(2), (2020)

28. R. Djalante, J. Lassa, D. Setiamarga, A. Sudjatma, M. Indrawan, B. Haryanto, C. Mahfud, M. S. Sinapoy, S. Djalante, I. Rafiana, L. A. Gunawan, G. A. K. Surtiari, and H. Warsilah, Progress in Disaster Science, 6, (2020)

29. T. S. Edriani, A. Rahmadani, D. M. M. Noor, Indonesian J of Applied Mathematics, 1(2), (2021)

30. J. E. Nelwan, J of Public Health and Commun Medicine, 1 (2), (2020)

31. C. J. Neiderud, and MD. Infection Ecology \& Epidemiology, 5 (1), (2020)

32 E. Alirol, L. Getaz, B. Stoll, F. Chappuis, and L. Loutan, The Lancet Infectious Diseases, 11 (2), (2011)

33 H. Harapan, N. Itoh, A. Yufika, W. Winardi, S. Keam, H. Te, D. Megawati, Z. Hayat, A. L. Wagner, and Mudatsir, J Infect Public Health. 13 (5), (2020)

34. N. Mona, J Sos Humaniora Terapan, 2 (2), (2020)

35 N. K. Agusintadewi, Building a Culture of Disaster Response Based on Local Wisdom in Indonesia, in National Seminar on Architecture and Spatial Planning, Samarta, 2019, Bali, Indonesia (2019)
36. B. Prasetyo, Kearifan Lokal sebagai Basis Mitigasi Bencana. Seminar Nasional FST-UT 2019, Jakarta, Indonesia, (2019)

37. C. T. Mukuruva, Community-Based Emergency Management: A Case Study on a Cholera Outbreak in Zimbabwe, Thesis, (Auckland University, Auckland, 2012).

38. K. J. Farkas, and J. R. Romaniuk, Society Register 4 (2), (2020)

39. B. Yanti, H. Priyanto, and T. Zulfikar, Martabe: J Pengabdian Kepada Masyarakat, 3(1), (2020).

40. S. Lardo, J Pertahanan \& Bela Negara, 10(1), (2020)

41. S. Notoatmodjo, Health Promotion and Health Behavior (Revised Edition), (Rineka Cipta, Bandung, 2012)

42. Bahagia, B. Hudayana, R. Wibowo, and Z. Anna, Forum Geografi, 34 (2), (2020)

43. Z. Aidha, Z. and R. A. Harahap, Tropical Public Health J, 1 (1), (2021)

44. R. Putnam, Bowling Alone: The Collapse and Revival of American Community, (Simon and Schurster, New York, 2000)

45 J. S. Coleman, Social Capital in Creation of Human Capital, (University of Chicago Press, Chicago, 1989)

46. J. Field, Social Capital (translated by Nurhadi), (Kreasi Discourse, Bantul, 2010)

47. Hasbullah. Social Capital (Towards Excellence in Indonesian Human Culture). (United Press. Jakarta, 2006)

48. S. Personal, J National Security, 7(2), (2020) 